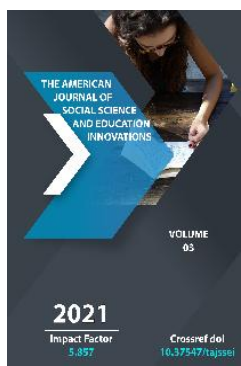

\title{
The Beginning Of A New Era In The Study Of The History Of World War li In Uzbekistan
}

\section{Ulugbek Saliev}

Candidate Of Historical Sciences, Senior Lecturer Of The Fergana Medical Institute Of Public Health, Uzbekistan

\section{ABSTRACT}

In the Second World War, the multinational people of Uzbekistan showed great courage and perseverance on the battlefields and behind the front and made a worthy contribution to the victory over fascism. One of the urgent tasks today is to prepare a comprehensive scientific-historical book or collection of documents, reflecting the hard and difficult life of the Uzbek people on the front and behind the front during this bloody war, that particularly contributed to the victory over fascism. Such resources will be of paramount importance to convey to future generations the great work done by our people during the war, its strong will and heroism, the truth of that time, to educate them in the spirit of patriotism and courage.

\section{KEYWORDS}

World War, mobilization, defense of the Motherland, courage and fortitude, volunteer fighters, infantry battalions, combat mission, Uzbek archers, artillery, ambush, the Battle of Stalingrad.

\section{INTRODUCTION}

An objective and just study of the human qualities of the people of Uzbekistan during the Second World War, their worthy contribution to the victory over fascism, is 
important for historical memory and the future. It should be noted that the resolution of President Shavkat Mirziyoyev dated October 23, 2019 "On the worthy celebration of the 75th anniversary of the victory in World War II" was of great importance. As the President said in his Address to the Oliy Majlis on January 24, 2020: "In 2020, the 75th anniversary of the victory in World War II will be widely celebrated internationally. We are all justifiably proud of the invaluable contribution of our brave, invincible and noble people to the great victory. The head of state particularly noted currently available opportunities such as to study previously closed archival documents and materials unknown to the scientific community, that the cooperation with archival organizations of the former Soviet republics and abroad, museums and foundations, historians and specialists strengthened with the general public. Besides, it is happily claimed that we have very important new information about our heroic ancestors, which is now widely covered in the media in books and albums, and a truly new era in the study of our history in World War II has begun." [1]

\section{MATERIAL AND METHODS}

"Today, we have every reason to say that a new phase in the study of our World War II history has begun. Of the $6,551,000$ people who lived so far at the start of the war, 1.5 million were estimated to have taken part in the war. According to the latest data, 1 million 951 thousand people were sent from Uzbekistan to the front to take part in hostilities. This means that one in three Uzbeks took up weapons in the fight against fascism, "said Shavkat Mirziyoyev.

"... ex-combatants ... Some of them became disabled as a result of the war. People who love each other as if they were consanguineous!" These people, who fought in the war, are well aware of the dangerous life of the wars. The whole company, the battalion, the regiment, the units disappeared in a matter of minutes in front of these people ... What a horror! For the motherland! For the people! We went to our deaths for the liverworts left at home! The number of dead and missing is 46 million from the Soviet Union alone. There is no denying it. From the White Sea to the Black Sea, from Lake Hassan to Gibraltar, in the forced retreat, in the heroic attacks, many were killed. Only a little over eight hundred of the thirteen thousand men in our artillery brigade returned home ... "[2] these words belongs to the fighter Ismoiljon Tukhtasinov who participated in The Great Patriotic War, which began on June 22, 1941, and aroused in Ismail's heart a sense of protection. By this time he was only twenty years old. He, like all the staff of the printing house, wrote an application to go to the front voluntarily. Finally, he was admitted to the 94th Uzbek Rifle Division as a volunteer. From the memoirs of Ismailjon Tukhtasinov; - The brigade was formed in August-September 1941 in Fergana. The brigade consisted mainly of volunteer fighters and was selected from Margilan, Fergana, Kokand, Tashkent, Kuva, Tashlak, Altiyarik, Rishtan, Baghdad.The government and public organizations of the republic closely helped to strengthen the brigade; the brigade was replenished at the expense of new forces. The brigade included infantry battalions, artillery and mortar divisions, machine guns, reconnaissance companies, sappers, and companies engaged in economic activities. The fourth infantry battalion joined us from Andijan. The valley's collective farms and state farms assisted with horses, and provided the brigade with food and fodder. Colonel I. Krasnov was appointed brigade commander. Former first secretary of the Fergana regional party committee $\mathrm{R}$. Kurbanov became a brigade commissioner. Executive Secretary of the Presidium of the Supreme Soviet of the Uzbek SSR A. Murodkhodjaev headed the political department. Battalions, batteries, divisions, companies were all selected as unit commanders. Experienced officers were 
selected for the headquarters. All measures were taken to increase the fighting. Thanks to the dedication of the volunteers, the enthusiasm of the commanders, all the work was carried out at the level of the front requirements. Putting the forces in place, distributing the cavalry, and conducting the exercises at the appointed time, at a high level, helped to prepare the units. The head of the political department, Abdullahoja Murodkhodjaev, was known for his zeal. With the help of devotees, party and Komsomol organizations were formed in the units. Work has begun. Political and mass events were intensified. In August, a general brigade rally was held in the village of Komsomol between the cities of Satkak-Fergana and Margilan, where the monument to the current 94th Brigade was located. In addition to representatives of the military command, the leaders of Uzbekistan - Usmon Yusupov, Yuldash Akhunboboev, Abdujabbor Abdurahmanov, famous writer Alexei Tolstoy, Uzbek writers, leaders of regional party, Soviet, Komsomol organizations, and the general public attended. Nakazs were given. The oath was taken ... Dozens of echelons left Fergana station. Hundreds and thousands of black-eyed men followed the men of the brigade. One by one the echelons went to Moscow without stopping. The archers did not even think about the terrible hardships and battles ahead. The first echelon landed in the Lyubertsy district of the capital. The rest came back and settled in the woods. People were armed. Zambarak, mortar was taken. Ammunition was distributed. Chairman of the Presidium of the Supreme Soviet of the USSR Mikhail Ivanovich Kalinin came to hand over the battle flag. - I know Uzbeks very well, said Mikhail Ivanovich, - a wonderful people. He honors the man and puts him in the net of his house. He makes a guest with Bori. He will not spare his life. If you vent your anger, the militant will correct your chase. Gives your impression. "We're in a bad situation at the front, the conditions are difficult," he continued after a pause. The German is a threat to Moscow. Aiming for the Volga River. Our task is to thwart the enemy's plan, to stop it, to break its power, to crush its equipment, to destroy it ... I trust you. Without the lion boys. Once the work has begun, you will finish it. I'm sure of it. I saw it with my own eyes when I was in your country. The Uzbeks have great courage. My friend Yuldash Akhunboboev told many stories. You are the descendants of Amir Temur and Ulugbek. May the spirit of these great men help you. Get ready for battle, my young boys! Homeland expects courage from you!

\section{DISCUSSION AND CONCLUSION}

The brigade was relocated that day. He set off on foot towards Kolomna. Along the way, weapons were delivered, exercises continued. Tasks were completed. With the appearance of rival planes in the sky, he tries to hide in all the trenches. Shortly afterwards, the brigade was escorted to the echelons. The train headed for the Stalingrad front. The third infantry battalion of the first combat test brigade in the defense of Stalingrad and the artillery division were assigned to the third battery fighters. They set to work. The 8- to 10-mile defensive distance was flat, with the exception of a single cliff at the back, and the surroundings were visible. On top of that, both units were not fully equipped with the necessary equipment for the battle, and no emergency measures were taken. No anti-tank shells or mines were brought. The commander of the union, N. Federchenko, lined up the fighting order. The first and third company infantry, machine gunners, tank fighters, artillerymen took their places. The machine guns were ambushed. Neighbors were contacted. The enemy troops were agitated. The Germans attacked. The bullets began to pour down like rain. The previous runners were worried. Unable to reach the trenches, he turned back from the bullets. The first attack ended. The next day, at dawn, the enemy attacked again with the help of tanks and transporters. After fierce fighting, the 
enemy retreated, leaving two tanks and a transporter damaged. The evening attack was terrible again. Three German tanks were smashed, and hundreds of people were killed. The Hitlerite command completed preparations for the attack in the middle of the month. New forces were brought to the front lines. The 6th Field and 4th Tank armies tried to surround the city from the east and west. The German army was about to cross the Don River and invade Stalingrad. The tankers want to tear our troops to pieces. The armies want to meet in the city. Uzbek archers fought valiantly against the enemy. The battle of life and death began. Five attacks were repulsed in exchange for blood. The next day the battle heated up again. Bombers appeared in the air. Tank and infantry attacks began. The archers defended their lands heroically as before. The answer to the invader is one: death. The tank fighters showed mastery. Khudoynazar Tukhtanazarov targeted an enemy tank approaching the trench.

He fired. The tank stopped as it collapsed. It burned. From the second bullet the flame rose into the sky. The second tank, which was trying to bypass, was hit from the side. The anger of the PTR chin boils. The gunmen who detached from the tank were bitten to the ground. The third tank dug a ditch where Tukhtanazarov was.Uzbek artillerymen brutally killed the enemy. A car loaded with military equipment was set on fire. A company of enemy soldiers was wiped out. The gunmen, who had invaded the battery, were killed in a hand-to-hand battle. Several tanks were fired. - Let the slogan "There is no step back" come to your mind! - This is how the head of the political department of the brigade A. Murotkhodjaev concluded his conversation in the ditch. - This is the slogan of the Communist Party. The task of the Soviet people. Homeland Security. The word of our parents, brothers and sisters. It is the sacred duty of each of us to serve. The goal was to keep the enemy out of Stalingrad. Several bombs dropped on the earth destroyed the places.

Artillery, six-barreled mortars roared incessantly. Soon the gunman, armed to the teeth, attacked with infantry using more than sixty tanks. Enemy tanks were damaged by direct shells fired, stopped. The infantry was killed. The Germans returned, leaving their burned cars and tanks on the field. Soon the attack began again with new forces. The archers did not come empty this time either. Ahmad Toshbaev, Kombat Khonkeldiev and other commanders demonstrated their skills. The parts helped each other. The Stalingrad Warrior-Stalingrad Warrior newspaper wrote about this in detail.

The enemy intensified the attack despite the casualties. A company of machine gunners attacked the battalion on the right with the help of 15 heavy tanks. A battalion of machine gunners, using tanks and planes, attacked the 9th Company. The archers stood alert. They smiled from the trenches in the danger of siege. All weapons were fired upon. Fuel-filled bottles were thrown into the negatively marked tanks that reached the top of the trench. Dozens of enemy tanks bit the ground. Courage always drives cowardice. The archers had such a quality. Ahmad Toshbaev fired a refueling bottle and set fire to an enemy tank. In this battle he died heroically. The artillerymen did not retreat. They repulsed the attack for seven hours. Bombs falling in the sky, bullets raining down, tanks invading, infantry attacking - nothing could repel the resistance of the brave archers.

The battle reached its climax. The Germans began to come from four directions. Kurshov became narrower and narrower. The commander of the reconnaissance company was Captain Captain Sobirjon Akhunjanov (now 1991), a resident of Tashkent. People were divided into groups. Liaison officers, sappers, medics, staff, commandant's staff, cooks, secretaries joined the ranks. The 
rotation went into defense. The insane throwing of the Germans, the tanks were stopped. The cracks were destroyed. The battle flag and important documents had to be taken to a safe place. This S. Akhunjanov's scouts did it. They broke through the siege. The commanders remained in the line of defense. Neighbors helped end the siege. The bloody battle continued day and night. Unprecedented heroism, patriotism, cohesiveness, patience, perseverance, extreme discipline were demonstrated. The Soviets proved in practice what they were capable of. 53 enemy tanks and 15 vehicles were set on fire. More than a thousand soldiers and officers were killed. The planes were shot down. In return for heavy casualties, the enemy captured some important positions.

"In unequal battles, the 94th OSB artillery showed heroism and courage in repelling enemy attacks," the front-line newspaper said. - Brigade soldiers realized their duty. They embody patriotism. Their bravery in carrying out the order is equal to that of Borodino in history. In time, the names of these heroes will be written in golden letters $" . .$.

The 94th Uzbek Rifle Brigade experienced heavy fighting. No matter how hard the enemy tried, despite repeated attacks and casualties, the brigade was unable to break through the defensive area. After two nights of secret training, he gathered strength and attacked Shumilov's army from the sidelines. A large force, a German relying on new tanks, is about to enter the city with a single attack. The enemy came out of the river with great force. Passed some places. Ours was ready for a counterattack. The command transferred the 94th Brigade and other units to General Shumilov. An order was issued to move to a new location. The brigade was preparing to occupy two villages. The Germans infiltrated the decisive areas despite heavy casualties. The Uzbek archers attacked. The German opened fire with all his weapons. The archers approached the trenches, using deep, single, low-hill, stone. The Germans did not expect this. A hand-to-hand fight ensued. This is where the mastery of the Uzbek boys came in handy. Encouraged by the initial victory, the archers chased and chased the enemy step by step.

Intelligence Route S. Akhundjanov was at the forefront of the attackers. Islam Magametov's battalion stood out for its courage. A battalion of Khorun Irmatov's infantry killed the Germans. An ordinary soldier, Abdukadir Abdunazarov, set fire to an enemy tank with a bottle filled with fuel. Husniddin Khankeldiev bit 12 Nazis, threw a grenade at his machine gunners and opened the way. The miners destroyed the trenches. Politruk Akbar Kozakov encouraged the shooters to fight, but remained in the line despite being seriously wounded.

"The homeland is behind us. The Volga River ... There is no going back one step. When we die, we die with honor. The order ended with the words: "Withdrawal is a crime." The archers prepared to repel the new attacks.

Colonel Krasnov of Kombrig saw the enemy's thirty tanks and infantry moving in a hurry from his observation post towards the artillery division. The command declared the firing on the front line. This inspired the fighters. The brigade stood firm in the area assigned to it, repulsed enemy attacks, and exhausted [3].

In the 56 days of fierce battles on the outskirts of Stalingrad, the brave sons of Uzbekistan showed real heroism, yet there were many losses .... We have to tell the wars, we have to write, we have to remember, because let our generation, our grandchildren know that our peace, our present prosperous life was achieved at the expense of hardships and losses, "our hero recalls. (Ferganskaya Pravda, August 15, 1991, 154). 
After the battles on the threshold of Stalingrad, Ismail Tukhtasinov was awarded the medal " For Courage". He was injured. He soon returned to the battlefields again. Ismail Tukhtasinov was awarded the Order of the Red Star for his heroism in the battle for the Morozovo railway station on the outskirts of Stalingrad. Among the fighters of the 94th Artillery Brigade, Ismail Tukhtasinov showed more heroism in the battles for the settlements of Ushakova, Rubashkino, Astakhovo, in the battles for the city of Rostov-on-Don ...

In the fierce battles in the village of Mikhailovka, there were particularly heavy casualties, unprecedented losses, after which the 94th Artillery Brigade was added to the 266th Artillery Division (The Truth of Fergana, April 28, 2001).

This division was named Artemovsk-Berlin, Guards of the Order of Suvorov with red flag (Guards Red Banner Order of Suvorov, Artyomov-Berlin Division). (The Truth of Fergana, August 15, 1991, 154) The 266th Infantry Division took part in the liberation of Ukraine, Moldova, Romania, and Hungary and reached Berlin. In these battles, Ismail Tukhtasinov showed real courage, bravery, the qualities of a warrior who perfectly performs every task of a commander. Kim Eliseevich Naumenko's book "266th Artemovsko-Berlinskaya", published in 1987 by the Moscow publishing house in Moscow, describes the exploits of Ismail Tukhtasinov in the 266th Artillery Division. (Kim Eliseevich Naumenko. "266-ya Artemovsko-Berlinskaya" .- Moscow: "Moscow" 1987. -51-70 p.)

\section{ACKNOWLEDGEMENT}

"During the war, I was wounded three times in battles, and once I suffered a severe concussion," recalls Tukhtasinov. Among the Odessa cadets we crossed the Black Sea to Constanta, and then with the rest to Bucharest "... (The Truth of Fergana, August
15, 1991, 154). Ismail Tukhtasinov took part in hostilities in Hungary after Romania. The fierce battles, especially for the railway station near Budapest, will never be forgotten, as this railway station was lost three times ... (The Truth of Fergana, August 15, 1991, 154). Ismail Tukhtasinov was wounded for the last time in this battle. He was demobilized in April 1945. Four days before the Victory Day, on May 5, 1945, he came to his father's house in the city of Margilan safe and sound.

\section{REFERENCES}

1. Resolution of the President of the Republic of Uzbekistan dated October 23, 2019 No PQ4495 "On the worthy celebration of the 75th anniversary of the victory in World War II."

2. Shamsutdinov R. On the contribution of the people of Uzbekistan to the great victory (1941-1945) .- Tashkent: "Akademnashr", 2020.-4 p.

3. Tukhtasinov I. Uzbek archers.-Tashkent: “Uzbekistan", 1991.-P.3.

4. Kim E.N. "266-ya Artemovsko-Berlinskaya" .- Moscow: "Moskva" 1987. -51-70 p.)

5. Amirov K.M. From Volga to Alp.-Moscow: Military publishing house.1987g.

6. Ферганская правда August 15, 1991 №154.

7. Fergana Truth, April 28, 2001. 